\title{
PECULIAR MORPHOLOGY OF SOME MICRO. ORGANISMS ACCOMPANYING DIATOMACEAE PRELIMINARY REPORT
}

\author{
PAVEL NEMEC and VOJTECH BYSTRICKÝ \\ Chair for Technical Microbiology and Biochemistry, Slovak Technical University \\ Laboratory for Electron Microscopy, Bratislava, Czechoslovakia \\ Received for publication, Feb. 23rd, 1962
}

\section{INTRODUCTION}

Problems connected with the study of the coexistence of diatomaceae (Bacillariophyceae, Diatomaceae) and bacteria arose at the end of the last century, when BEIJERINCK (1) introduced a method suitable for studying unicellular algae by bacteriological techniques, which made the cultivation and maintaining of single species of algae possible. Another problem was the cultivation of absolutely pure culture of algae free from contamination by other microorganisms such as bacteria or lower fungi. Although PringshEIM (2) maintained that the presence of bacteria does not interfere with morphological studies of algae, the situation is obviously more complicated in the studies of biochemical processes taking place in non-axenic cultures. Before the advent of antibiotic substances, bacteriological techniques such as diluting, spreading, etc. were used for the elimination of bacterial contamination $(3,4,5,6)$.

We know that some algae are capable of giving off organic compounds, mainly sugars and possibly also amino acids, into the nutrient medium $(7$, $8,9)$. These compounds can be metabolized by soil heterotrophs, especially bacteria; motile species are possibly even chemotactically attracted to form more or less dense populations. Some papers suggest a possible symbiotic relation between algae and bacteria in the soil $(10)$, others presume the existence of antagonistic relations $(11,12)$ due to antibiotics produced by either side of the microorganisms.

While studying relations between soil-diatomaceae and bacteria we found some morphological anomalies of bacterial cells, including appearance of caulobacterium forms $(13,14,15,16)$ which are not very common in the nature. The present paper deals with these morphological anomalies occurring in the biocoenosis of soil diatomaceae and bacteria.

\section{MATERIALS AND METHODS}

The culture of diatomaceae was obtained by inoculating garden soil (from 
the vicinity of Bratislava) into Richters' liquid medium $\left(0.2 \mathrm{~g} \mathrm{~K}_{2} \mathrm{HPO}_{4}, 0.2 \mathrm{~g}\right.$ $\mathrm{KNC}_{3}, 0.05 \mathrm{~g} \mathrm{MgSO}_{4}, 0.01 \mathrm{~g} \mathrm{~K}_{2} \mathrm{Si}_{2} \mathrm{O}_{5}, 1000 \mathrm{~g} \mathrm{H}_{2} \mathrm{O}$ ). After four weeks' cultivation under constant electric light, a subculture was made on RICHTERs' agar (the same composition as above plus $1.8 \%$ extracted agar) and again cultivated under electric light.

Electron micrographs were taken using a czechoslovak electron microscope TESLA BS 242. Specimens for electron microscopy were prepared as follows: with a bacteriological loop small amounts of microorganisms were taken from the surface of the colonies and transferred into small drop of distilled water. From this suspension, after diluting, microdroplets were transferred onto usual formvar films on grids, and after drying, obliquely shadowed in vacuo with an alloy of platinum and gold.

\section{EXPERIMENTAL RESULTS}

Electron micrographs of the mixed cultures on Richters' agar revealed the existence of the following forms of bacteria.

1) Rodshaped bacteria ('A' Fig. 1.) of usual type, with the length of between 1 and $2.4 \mu$, and width between 0.4 and $0.8 \mu$. The inside of these cells is more or less homogenous, the cytoplasm contracted (dehydration effect), and the membrane is well discernible.

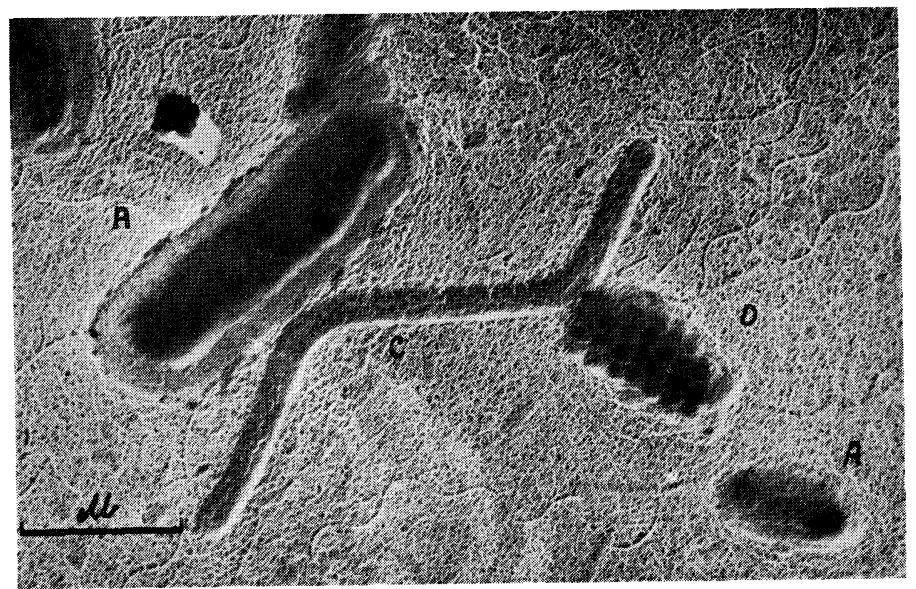

Fig. 1. Bacterial biocoenosis with diatomaceae.

A: rod-shaped bacteria. C: filaments, D: bacterium filled with uniform, spherical bodies.

2) Caulobacteria (Caulobacteriaceae, Bergey 1948), ('B', Fig. 2.). Their dimensions are about the same as those of the bacteria described above. Caulobacter, which is a bacterium with a stalk, has been described by Houwink $(13,14)$ as a parasitic microbe feeding on common saprophytes, e.g. B. subtilis. In Fig. 3 one of them is depicted with the stalk intruded 


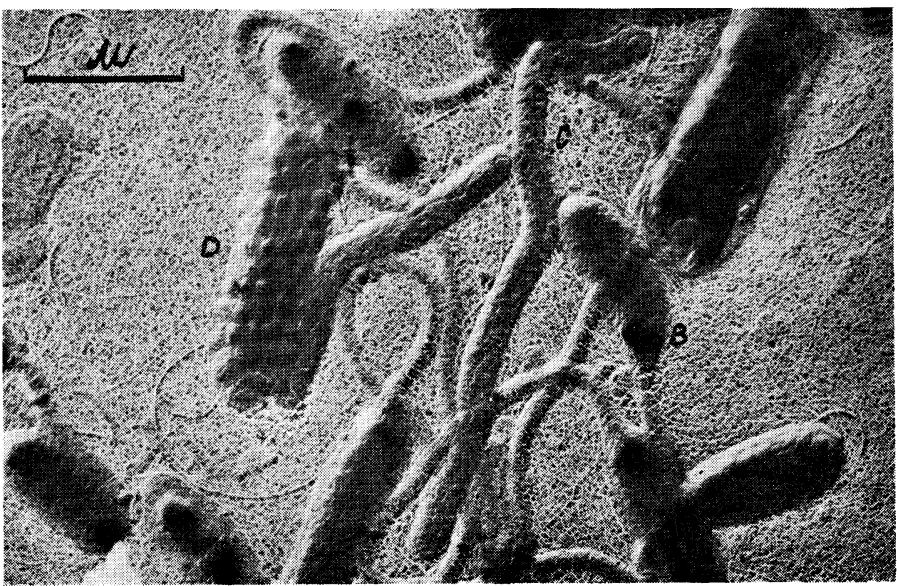

Fig. 2. Bacterial biocoenosis with diatomaceae.

D: caulobacterium; C, B: same as those in Fig. 1.

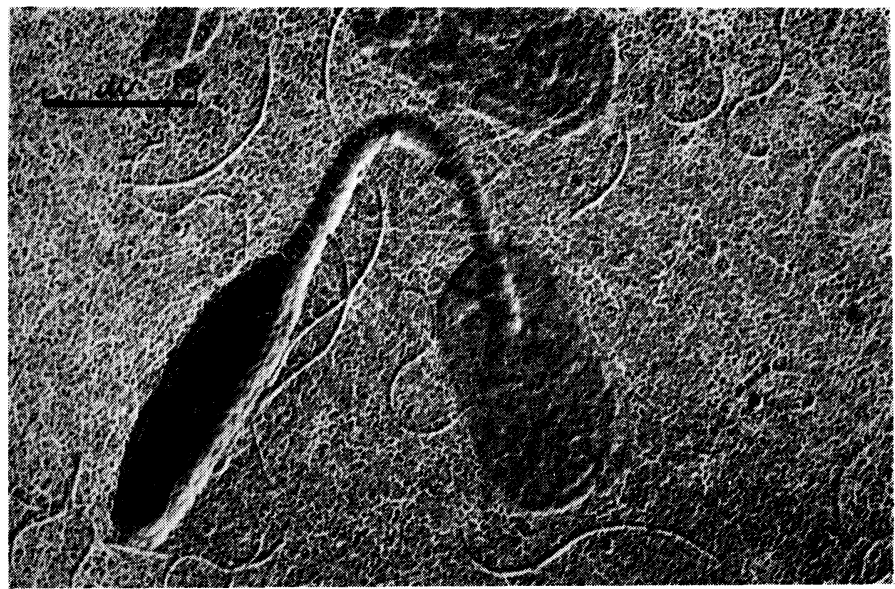

Fig. 3. Caulobacterium with a stalk intruded in empty bacterial cell.

into a now already empty bacterial cell. Fig. 4 shows a microcolony of such caulobacteria.

3) In the bacterial biocoenosis with diatomaceae, filaments (Figs. 1, 2, ' $C$ ') were fairly often found. These filaments, 3 to $6 \mu$ long and of a uniform diameter of about $0.2 \mu$, are also discernible under the optical microscope; whether they are microorganisms or disconnected flagella of some bacteria is not clear.

4) We also observed objects of about the size of usual rodshaped bacteria 


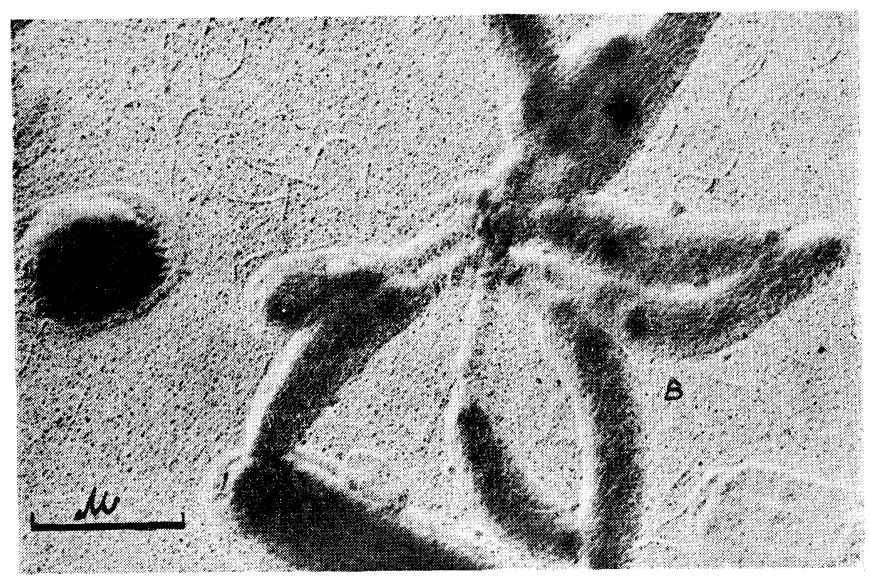

Fig. 4. Microcolony of 'caulobacteria.

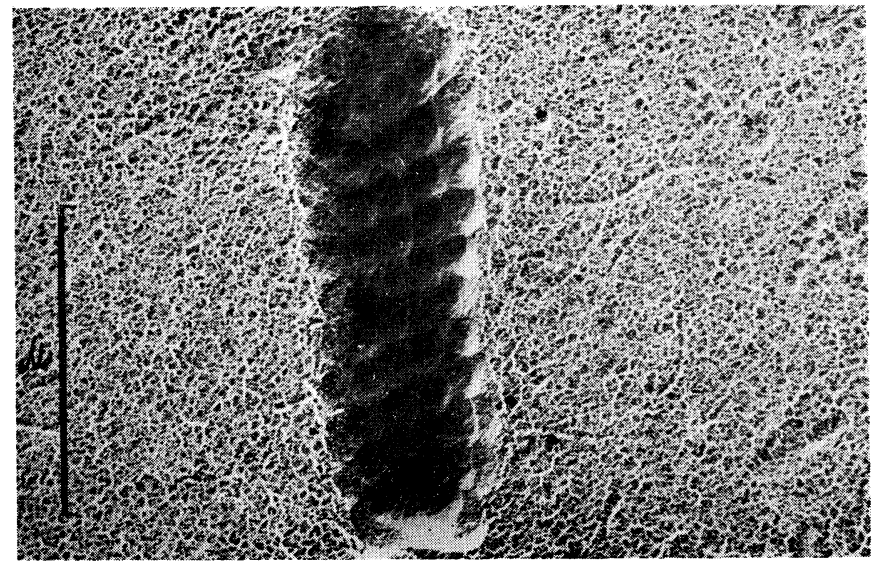

Fig. 5. Rodshaped bacterium, containing many uniform, spherical bodies in helical arrangement.

but evidently consisting of clearly discernible uniform spherical bodies, about $0.1 \mu$ in diameter (Figs. 1, 2, 'D', Figs. 5, 6, 7), which obviously could not be resolved by the optical microscope. These bodies are in the inside of cells and arranged in a suprisingly regular pattern; in each such cell a clearly visible helical arrangement of the spherical bcies can be observed. The helix has a characteristic slope of about $20^{\circ}$. Very roughly estimated, a cell contains 40 to 120 of the spherical bodies. A membrane could not be discerned with certainty in such cells. Very few of the cells in our specimens were of this type. We found them again in the same culture a few weeks later. In a subculture we found either single spherical bodies or bodies in 


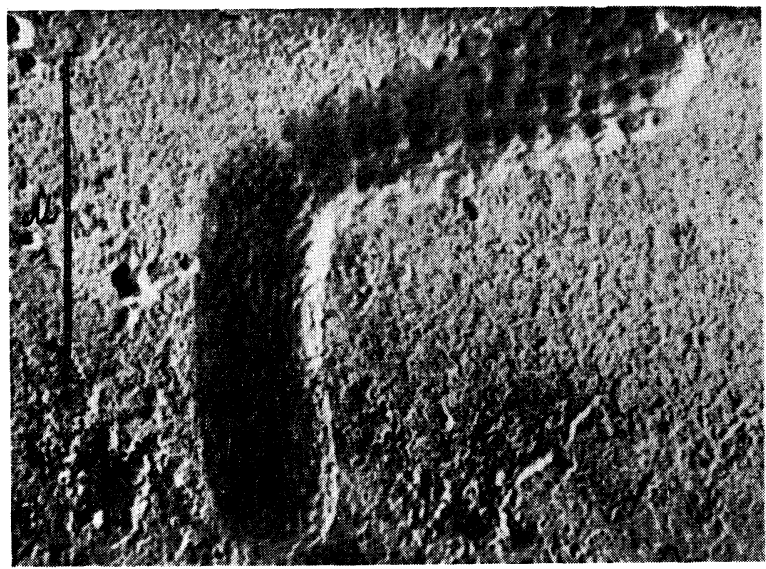

Fig. 6. Bacterial cell with spherical bodies lying in close vicinity of a usual bacterial cell.

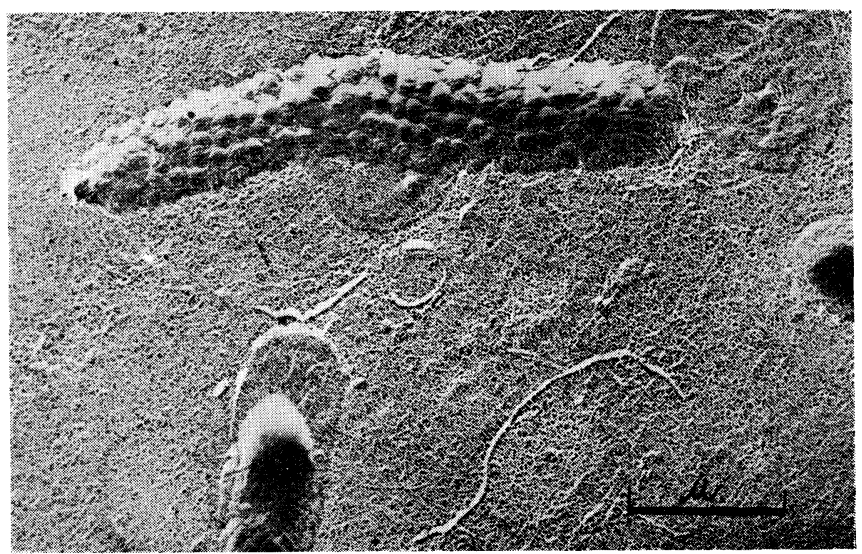

Fig. 7. Bacterial cell with uniform spherical bodies.

contact with bacterial cells (Fig. 11), but no objects of the type such as illustrated in Fig. 7.

The studied diatomaceae belongs to the species Pinnularia viridis, commonly found in soils (Fig. 8). In the fixed and stained (phenol-crystal violet) specimens placed under the optical microscope, rod-shaped bacteria of usual appearance could be seen generally surrounding cells of diatomaceae. In Figs. 9 and 10 are shown the electron micrographs of cells of diatomaceae surrounded by bacteria. Rod-shaped bacteria and filaments do not stain easily. As already mentioned, spherical bodies inside cells, as described under 4 , could not be resolved by the optical microscope. In living speci- 


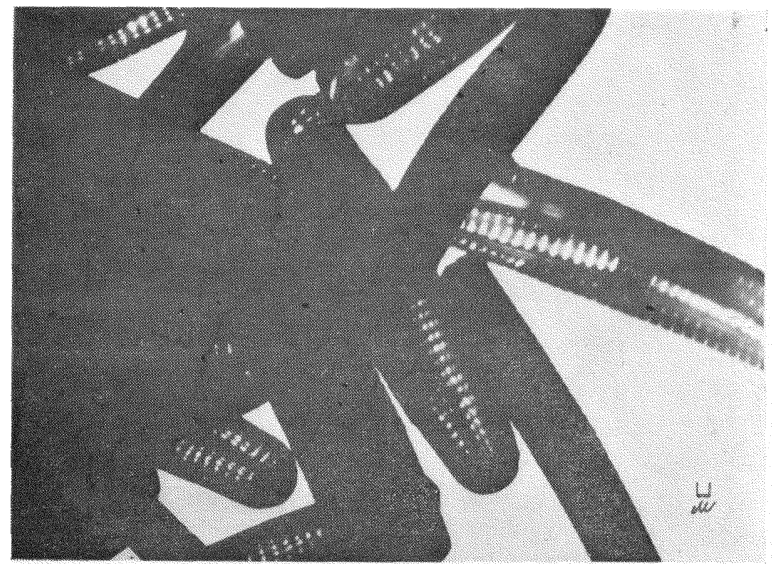

Fig. 8. Cells of diatomaceae, Pinnularia.

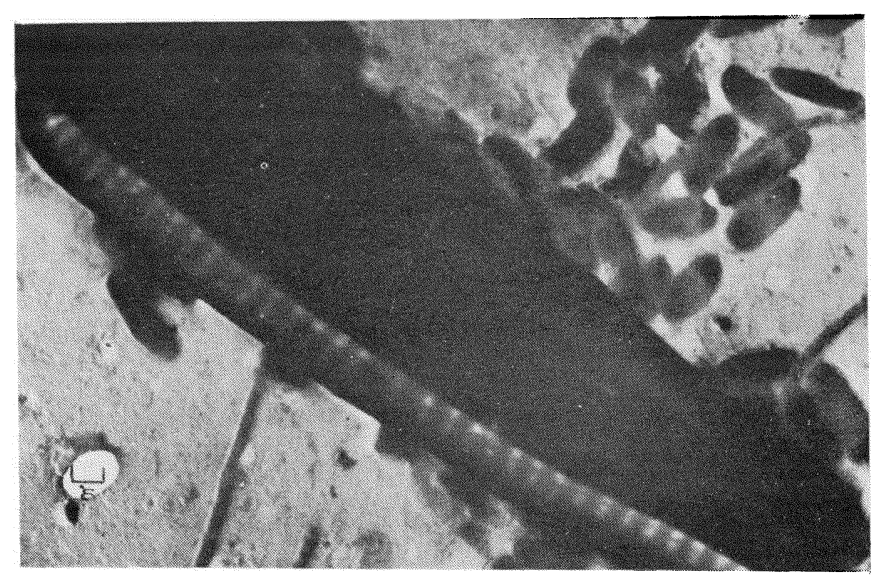

Fig. 9. One cell of Pinnularia with bacterial cells attached to it.

mens observed with the phase contrast microscope, the rod shaped bacteria were actively moving, whereas the filaments did not move. Electron micrographs of cells of diatomaceae are shown in Fig. 8.

\section{DISCUSSION AND CONCLUSIONS}

Of special interest is our finding of bacteria containing uniform spherical bodies about $0.1 \mu$ in diameter, which were arranged in a surprisingly regular pattern. We have never found a description of something similar in papers from available sources. The following alternative interpretations may be made for the observed remarkable phenomenon. 


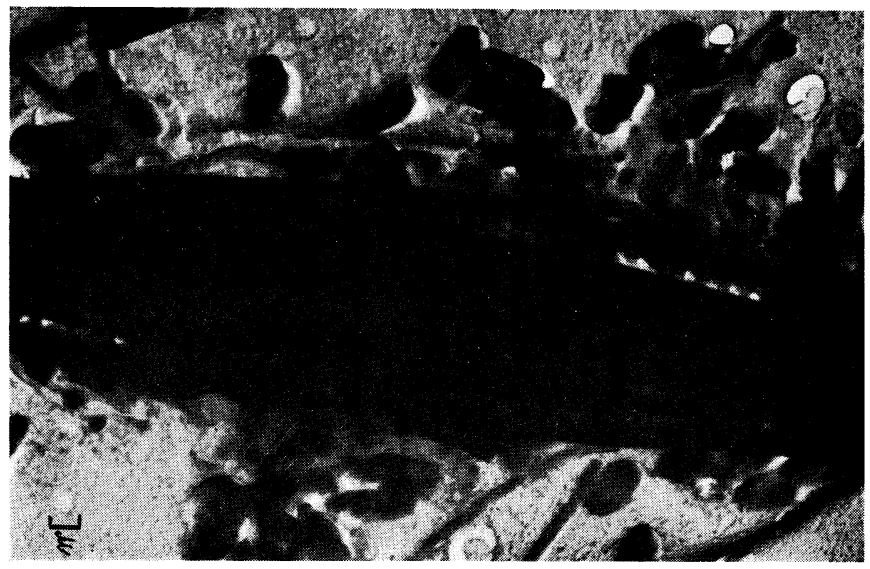

Fig. 10. Same as Fig. 9.

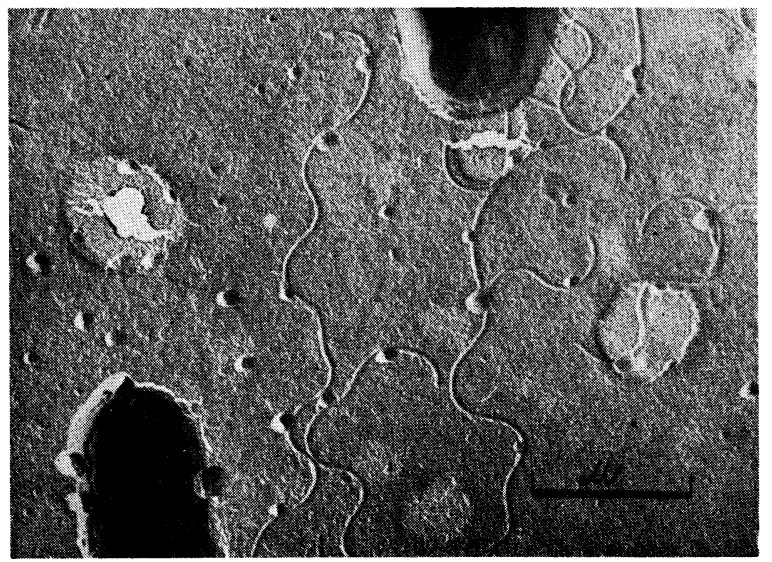

Fig. 11. Single spherical bodies, some of them in contact with a bacterial cell.

A) The objects might be cells subjected to the action of bacteriophages. This supposition seems to be supported by the dimensions of the spherical bodies and their estimated number in a cell. Although in a subculture spherical bodies lying free and in contact with bacterial cells were observed (Fig. 11), this finding is not sufficient to explain the described morphological features as being a phenomenon caused by bacteriophage. The regular helical arrangement of the spherical bodies inside the cells suggests that they were produced in a coordinated way in such a manner that the resulting spatial formation gives the impression of an entity. Existence of phagelike particles in bacterial cells prior to their lysis is usually observed in phage 
infections; however no case has even been reported, in which the phage particles in infected bacterial cells form a morphologically coordinated entity.

B) We might have seen a stage of a life cycle of an organism (cyclogeny, which has already been described and discussed in principle many times during the last fifty years), the forming of some sort of sporangium or of the so-called L-forms of bacteria. If this is the case, we might have observed unique morphological features unknown up to now. We must stress, however, that up to now were not able to prove that the observed spherical bodies (Fig. 11) are viable.

C) We might have been dealing with cells of a hitherto unknown microorganism, "submicrococcus," growing in the helical pattern described.

Experiments are now under way which, we hope, will allow us to explain the described phenomenon.

The fact that the observed anomalous morphology of bacterial cells has not been reported heretofore may not be suprising, if the phenomena were peculiar events occurring in the biocoenosis of bacteria with diatomaceae. Until now there have been only few papers dealing with the problem of coexistence of diatomaceae and bacteria and, as far as we know, no relevant observations have been made with electron microscopy.

\section{SUMMARY}

This preliminary report deals with the morphology of bacteria growing in biocoenosis with a diatomaceae Pinnularia. Electron micrographs of the mixed cultures showed the esistence of: (i) rod-shaped bacteria of usual type, (ii) typical caulobacteria (iii) thin filaments, and (iv) rod-shaped bacteria of usual dimenstions but filled with uniform spherical bodies about $0.1 \mu$ in diameter, which were arranged in a regular helical pattern. Significance of the last mentioned phenomenon was discussed suggesting the possibility either of a bacteriophagy or of some sort of cyclogeny, e.g. L-forms of bacteria, or the existence of a hitherto unknown submicrococcus.

\section{LITERATURE}

(1) M. W. BeIJERINCK: Botan. Ztg. 48, 725 (1890).

(2) E. G. Pringsheim: Algenkultur. Berlin-Wien, 1921, p. 378.

(3) O. Richter: Ber. d. Deutsch. bot. Ges. 21, 493 (1903).

(4) R. HARDER: Ztschr. f. Botan. 0, 155 (1917).

(5) S. V. GoRJunova: Chimiceskoj sostav $i$ priziznennyje vydelenija sinezenoj vodorosti Oscillatoria splendida. Moskva 1950.

(6) P. NemEc: Zaklady mikrobiologickej laboratornej techniky. Bratislava, 1954, p. 327 .

(7) A. KNOGH, E. LANGE: Bio:hem. J. 24, 1666 (1930).

(8) G. E. FogG, D. F. Westlake: Intern. ver. Limmologie 12, 219 (1955). 
(9) R. A. LEwIN: Canad. J. Microbiol. 2, 665 (1956).

(10) A. R. Werner: Dokl. Akad. nauk SSSR, 4 (9), 145 (1935).

(11) S. PrAT et al.: Science 99, 251 (1944).

(12) R. HARder, A. OpermanN: Arch. Microbiol. 19, 398 (1935).

(13) A. L. Houwink: Ant. v. Leeuwenhoek 21, 49 (1955).

(14) A. L. Houwink: Nature (London) 168, 654 (1951).

(15) V. BYSTRICKY: Biologia SAV 9, 566 (1954).

(16) O. Kandler, C. Zehender, O. Huber: Arch. f. Mikrobiol. 21, 57 (1954). 